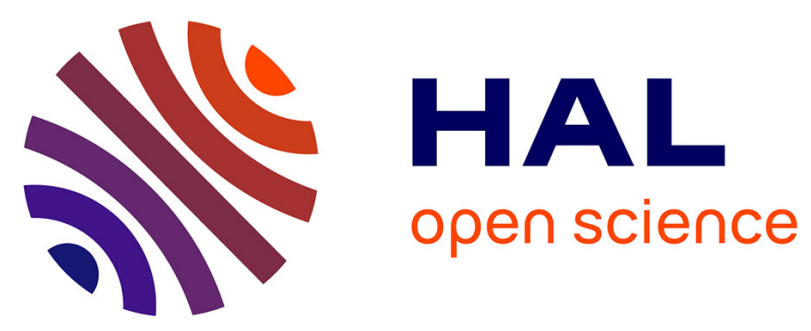

\title{
Collaborative Production Chains: A Case-Study of Two Agri-Food Companies in Brazil
}

Yuri Lima, Silvia Morais, Luis M. Araujo, Daiane Da S. A. Castelo Branco, Irenilza De A. Nääs

\section{- To cite this version:}

Yuri Lima, Silvia Morais, Luis M. Araujo, Daiane Da S. A. Castelo Branco, Irenilza De A. Nääs. Collaborative Production Chains: A Case-Study of Two Agri-Food Companies in Brazil. IFIP International Conference on Advances in Production Management Systems (APMS), Sep 2019, Austin, TX, United States. pp.123-128, 10.1007/978-3-030-30000-5_16 . hal-02419221

HAL Id: hal-02419221

https://hal.inria.fr/hal-02419221

Submitted on 19 Dec 2019

HAL is a multi-disciplinary open access archive for the deposit and dissemination of scientific research documents, whether they are published or not. The documents may come from teaching and research institutions in France or abroad, or from public or private research centers.
L'archive ouverte pluridisciplinaire HAL, est destinée au dépôt et à la diffusion de documents scientifiques de niveau recherche, publiés ou non, émanant des établissements d'enseignement et de recherche français ou étrangers, des laboratoires publics ou privés.

\section{(c)(1)}

Distributed under a Creative Commons Attribution| 4.0 International License 


\title{
Collaborative production chains: A case-study of two agri-food companies in
}

\section{Brazil}

Yuri Claudio C. de Lima ${ }^{[0000-0002-3020-7235]}$, Silvia Piva R. de Morais [0000-0002-7813${ }^{9884]}$, Luis A. Mendes de M. Araujo ${ }^{[0000-0001-7638-8652]}$, Daiane da S. A. Castelo Branco [0000-0001-6104-5999], Irenilza de A. Nääs ${ }^{10000-0003-0663-9377]}$

${ }^{1}$ FACID/WYDEN, Teresina, Piaui, Brazil

${ }^{2}$ Graduate Studies in Production Engineering, Paulista University, São Paulo, Brazil

\author{
yuricclima@gmail.com \\ silviapiva6@hotmail.com \\ lamma82@gmail.com \\ daiane.algarves@ifma.edu.br \\ irenilza.naas@docente.unip.br
}

\begin{abstract}
A collaborative production chain is often understood as having a known degree of relationship among members of the chain to share risks and benefits that result in higher commercial performance than individual organizations. The current study aimed to analyze two production chains of cashew and honey in Northeastern of Brazil which work collaboratively. Characteristics of the chains were learned from interviews with technical personnel from agricultural extension office and farmers. Results indicate that despite the best harvest cashew farmers might have when the crops are pollinated by bees both partners are not fully satisfied with the collaboration. A partner might benefit from management items that help to assess collaboration performance more effectively such as joint efforts, sharing activities, collaboration value, adaptation, trust, commitment, continuous improvement, coordination, and stability. Supply chain collaboration improves the performance advantage and has a significant influence on firm performance; however, such an initiative needs to be understood as a win-win association by the partners to achieve the expected success.
\end{abstract}

Keywords: collaborative supply chains; cashew crop; honey production

\section{Introduction}

A collaborative production chain means that two or more independent companies work in association to plan and execute production operations more successfully than when acting alone. This concept is often used in the supply chain, suggesting a known degree of relationship among members of the chain to share risks and benefits that result in higher commercial performance than individual organizations [1]. One of the ways collaborative chains work is through the sharing of research [2]. Resource sharing refers to the process of influencing skills and leveraging assets in the supply chain partners. Resources may include physical resources such as area, manufacturing equipment, facilities and technology [3].

The interaction between the actors of the business environment, acting cooperatively and sharing the same vision, reduces efforts, such as greater agility, flexibility, quality of products and services offered to customers. The maturity and efficiency of the operationalization of the strategy between two or more companies present a strong 
relation and direction of the efforts, that together cooperate in the co-creation of value [4]. The collaborative initiative of a supply chain often comes from integrated solutions that result in economies of scale that eventually reduce costs and increase revenues. In some cases, there is a common base of needs or even a way to solve a common problem. Using IT, for example, can be a good example of collaboration. Often IT associates supply chain collaboration with inter-organizational process improvements along with information systems, allowing chain members to effectively deliver products to end customers at minimal cost [5].

Value food chains are the financing of income for small farmers in most developing countries. Authors present an innovative model for improving the maize value chain in India [6]. The open innovation business model approach can strengthen farmers identified weak links. The business model explicitly developed promotes information sharing, innovation, collaboration and feedback cycles within the value chain, as well as support cases from similar approaches. Another form of collaboration was discussed in perishable foods in agribusiness in Tanzania [7]. The authors' findings show that, in a fragmented value chain of preprocessed fruits and vegetables, actors are aware of each other, but very little formal cooperation occurs, and the transactions are market-based and price-driven. The business strategy is the creation of a chain that provides values and that works from a multiplicity of diversified processes [8].

About one-third of the world's food crops depend on varying degrees of pollinators - including management bees (Apis mellifera) and native bees $[9 ; 10]$ ). Pollination is considered an important ecosystemic service, essential for food production, favoring the production of higher quality fruits, weights and seeds [11]. Mainly in large areas of monocrops, whose pollination services offered by ecosystems are not always able to meet the high demand for pollination of the target crops [12]. The potential of pollination as an ecosystem service can be highlighted when associated with food production. [13] estimated between US\$ 235 billion and US\$ 577 billion. In Brazil, it is estimated that pollination related to agricultural production has an annual value of US\$ 12 billion [14]. In the U. S., the market for pollination services has grown so much in the past decade that beekeepers now receive a larger share of their income from pollination services than from honey production [15]. Pollination is crucial for the whole of flowering fruit plants. As cashew is highly pollinated by insects mainly bees, its activities in cashew intensive production play a vital role in increasing yield.

In Brazil, unlike the U. S. and European countries, the use of bees for pollination is quite scarce. In the Northeast region, it is common practice to rent hives for pollination of the melon, and in the South with the pollination of the apple. This fact, scarce pollination, can be explained by the diversity and presence of natural pollinators in Brazil, which has been decreasing considerably in recent decades due to deforestation, the use of agrochemicals and the lack of knowledge about the real importance of insects in pollination of crops [12]. The primary challenge of current beekeeping is the adoption of sustainable management practices appropriate to the different seasonality of the environmental conditions faced by these bees in most localities.

The present exploratory study aimed to investigate the collaborative production chain of two agricultural products (cashew and honey) in the semi-arid region of the state of Piauí, in the Northeastern region of Brazil. 


\section{Methods}

A qualitative case study was carried out, through the analysis of a scenario and interviews to identify, categorize, and analyze the collaborative chains of cashew and honey productions in the Northeastern of Brazil.

A scenario of the production chains (cashew and honey) that was the goal of the current study was draw-up based on bibliographical research. The scenario was compared with data collected directly from interviews of the representatives of the producers of these crops (4) and technicians from public agencies of assistance to the rural producer (2). In the interview questions related to the collaboration terms and satisfaction of the partners were asked.

\section{Results and Discussion}

Piauí is in the second rank amongst the Brazilian states with the most significant number of businesses focused on cashew and in the fourth rank with the largest number of establishments focused on beekeeping. The scheme of interface of the production chains is shown in Figure 1.

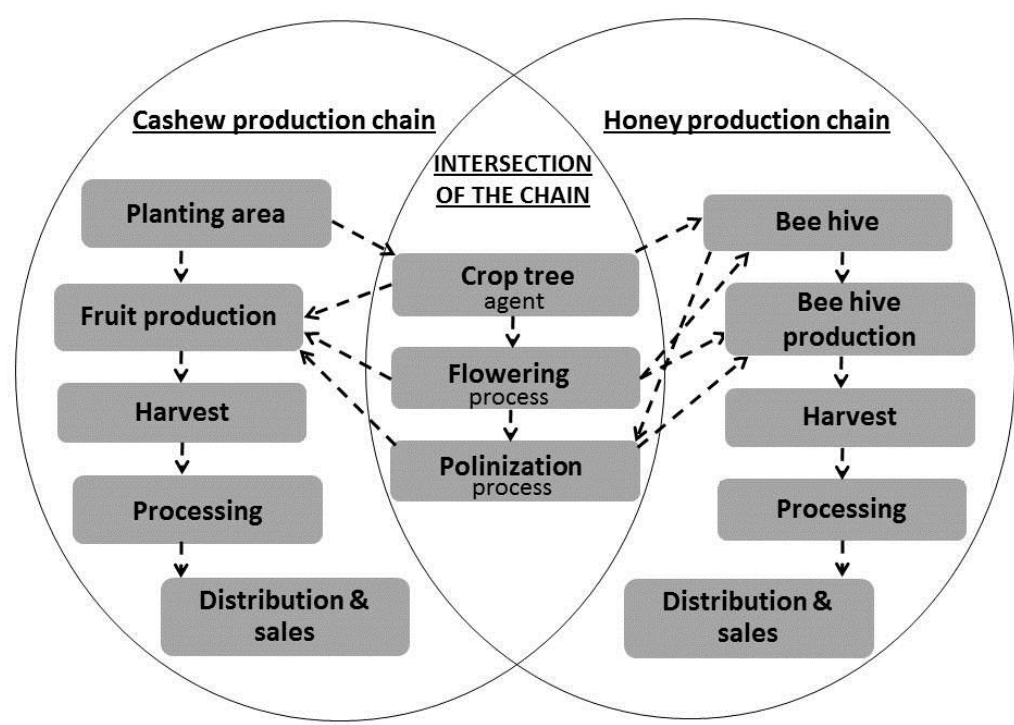

Fig. 1- Scheme of the two studied collaborative production chains cashew and honey.

Interviews with producers (4) and technicians (2) from the region's Technical Assistance and Extension Institute (EMATER) reported that the association between cashew production and honey production and that the percentage of honey production in this condition represents only $5 \%$ of all honey production the state. Such an issue is that because the costs are high. There are few beekeepers, classified as medium or large producers, and who has enough resources to cover the expenses of migratory 
beekeeping. While in the U.S. every winter (January to March), beekeepers move up to $55 \%$ of their bee colonies [16].

The movement of bee colonies throughout the country is driven mainly by two reasons: the provision of pollination services in different parts of the country (1) and the search for fodder to produce honey and guarantee the survival of the colonies in the winter (2). Farmers who grow crops that require or benefit from pollination (e.g., almonds) pay beekeepers to pollinate their crops [15].

Most of the income earned by beekeepers in the U. S. comes from pollination services that receive a higher share of their revenue from pollinating services than from honey production $[10 ; 15]$.

In the Northeast of Brazil, especially in the states of Ceará, Piauí, and Rio Grande do Norte, there are large areas of cashew (Anacardium Occidentale) crops both for internal consumption, and export (nut and peduncle). Because it is an attractive crop for bees, it is possible to produce monofloral honey from this flower [17]. Collaboration between the cashew producer and the beekeeper is critical to a win-win outcome. Such an interaction between those involved in the business, working collaboratively, reduces efforts and can improve the quality and quantity of products that will be offered to customers.

Studying the same crops in Benin [18], the authors found that between 25 and $72 \%$ of cashew flowers were not pollinated in nature because of the limitation of pollinators and also stated that an increase of $157.8 \%$ would be possible if the flowers received adequate pollen. Honey production and pollination services are activities that do not always go in collaborative ways [16]. One of the main obstacles to the development of the pollination market has been the results obtained with the use of bees as pollinators since beekeepers do not care about the pollinating efficiency of their hives, but only in producing as much honey as possible. Pollination results usually fall short of what would be expected. The insignificant results mean that farmers do not incorporate pollination services as factors of production of their agricultural activities, nor do they attract other farmers to use pollinators in their crops. The concern of beekeepers to adopt rational pollination programs that considered these and other factors would certainly significantly increase the efficiency of pollinating agents and the demand for their services $[15 ; 16]$.

The results from [2] indicate that supply chain collaboration improves the performance advantage and has a significant influence on the company's performance. The authors emphasize the fact that the production chain partners adapt to achieve appropriate synergies and create superior performance.

In the present case study, the collaborative initiative occurred aiming the improvement of the chains' production performance. The results from $[2 ; 5 ; 7]$ indicate that supply chain collaboration improves the performance advantage and has a significant influence on the firm performance. The authors emphasize the fact that the production chain partners trend to adapt to achieve appropriate synergies and create superior performance. 


\section{Final Remarks}

Despite the achievement on other urban-industrial collaborative supply chains, the key behavioral factors to enable an effective collaboration system for sustainable agri-food supply chains to require joint efforts, sharing activities, collaboration value, adaptation, trust, commitment, power, continuous improvement, coordination, and stability. The agri-food supply chain collaboration might benefit from these management items that help to assess collaboration performance more effectively.

It has been evident from the review of previous studies in the cashew production matter, that such collaboration has a broad scope to raise current cashew yields by supplementing pollination. Thus, learning from the success of beekeeping in other countries (The US, Benin, and Ghana), pollination can be complemented by the inclusion of beehives in the field to increase productivity.

\section{Acknowledgments}

The authors wish to thank Mr. Paulo Henrique Miranda, Mr. Jonas Alves dos Santos, and Mr. Eberson Alves dos Santos for the available information regarding the cashewhoney collaborative chain.

\section{References}

1. Simatupang, T. M., R. Sridharan, R. The architecture of supply chain collaboration. Int. J. Value Chain Management, v 1, p. 304-323, 2007.

2. Cao, M., Zhang, Q. Supply chain collaboration: Impact on collaborative advantage and firm performance. Journal of Operations Management, v.29, p. 163-180, 2011.

3. Harland, C.M., Zheng, J., Johnsen, T.E., Lamming, R.C. A conceptual model for researching the creation and operation of supply networks. British Journal of Management, v. 15, p.121, 2004.

4. Bonamigo, A., Rodriguez, C. M. T. O conceito Hoshin Kanri aplicado no gerenciamento da cadeia de suprimentos. Journal of Lean Systems, v. 2, p. 1-1, 2017.

5. Simatupang, T. M., R. Sridharan, R. The Collaborative Supply Chain. The International Journal of Logistics Management, v.13, p. 15-30, 2002.

6. Adekunle, A., Lyew, D., Orsat, V., Raghavan, V. Helping agribusinesses-Small millets value chain-To grow in India. Agriculture 2018, v.8, p.44. Available at: doi:10.3390/agriculture8030044. Accessed March 19, 2019.

7. Ndyetabula, D. W., Sørensen, O. J., Anna A. Temu, A. A. Agribusiness development and the role of value chain business associations: The case of dried fruits and vegetables in Tanzania, African Journal of Economic and Management Studies, v.7, p. 510-534, 2016.

8. Mintzberg, H., Quinn, J. B., Lampel, J., Ghoshal, S. O Processo da Estratégia: Conceitos, Contextos e Casos Selecionados. 4. ed. Porto Alegre: Artmed, 2007.

9. Klein, A.-M.et al. Importance of pollinators in changing landscapes for world crops. Proceedings of the Royal Society B: Biological Sciences, v. 274, n. 1608, p. 303-313, 2007.

10. USDA-NASS. Honey Report. National Agricultural Statistics Service, US Department of Agriculture. 2018.

11. Imperatriz-Fonseca, V. L., Nunes-Silva, P. As abelhas, os serviços ecossistêmicos e o Código Florestal Brasileiro. Biota Neotropica, v. 10, n. 4, p. 59-62. Instituto Virtual da Biodiversidade. Campinas, Brasil, 2010. 
12. Almeida, D. et al. Plantas visitadas por abelhas e polinização. Piracicaba: ESALQ - Divisão de Biblioteca e Documentação. Série Produtor Rural, Edição Especial, 40 p., 2003.

13. IPBES. The assessment report of the Intergovernmental Science-Policy Platform on Biodiversity and Ecosystem Services on pollinators, pollination and food production. Potts SG, Imperatriz-Fonseca VL, Ngo HT (eds). Secretariat of the Intergovernmental SciencePolicy Platform on Biodiversity and Ecosystem Services, Bonn. 552p. 2016.

14. Giannini, T. C. et al. The dependence of crops for pollinators and the economic value of pollination in Brazil. Journal of Economic Entomology, v. 108, n. 3, p. 849-857, 2015.

15. Ferrier, P.M., Rucker, R.R., Thurman, W.N., Burgett, M. Economic Effects and responses to changes in honeybee health. ERR-246, U.S. Department of Agriculture, Economic Research Service, March 2018.

16. Hitaj, C., Smith, D. J., Hunt. K. Honeybees on the move: Pollination services and honey production. Conference: 2018 Agricultural \& Applied Economics Association Annual Meeting. Washington, D.C., 2018.

17. Bendini, J. do N.; Souza, D. C. Caracterização físico-química do mel de abelhas proveniente da florada do cajueiro. Ciência Rural, v. 38, n. 2, p. 565-567, 2008.

18. Reddi, E.U.B. Under-pollination: a major constraint of cashew nut production. Proceedings of the Indian National. Science Academy v.53, n. 249-52, 1987. 